\title{
ANALISISASAS KEADILAN PADA PEMBAGIAN HARTA WARISAN MENURUT HUKUM ISLAM
}

\author{
Islamiyati \\ Fakultas Hukum Universitas Diponegoro Semarang \\ Jl. Prof. Sudharto No. 1 Tembalang Semarang \\ email: Islamiyati@yahoo.co.id
}

\begin{abstract}
Al-Qur'an surah An-Nisa'sentence 11 dan KHI of section 176 explaining that shares of between men and woman is two comparing one. Inheritance Law of principled Islam form proportional justice, and conception distributive justice its meaning a justice passing to each and everyone based by for its service or its rights.But in certain case, portion of division of heritage cannot that way, so long as there is certain reason is which might of according to Islam law, referred as by this of sulh ( settlement by agreement applying).
\end{abstract}

Keywords : Justice Ground, Heritage Division, Islamic Law

\section{Abstrak}

Al-Qur'an surat An-Nisa'ayat 11 dan KHI pasal 176 menjelaskan bahwa bagian warisan antara lakilaki dan perempuan adalah dua berbanding satu.Hukum kewarisan Islam berprinsip keadilan berimbang, dan berkonsep keadilan distributif (justice distributife) artinya suatu keadilan yang memberikan kepada setiap orang didasarkan atas hak dan kewajibannya. Namun dalam kasus tertentu, porsi pembagian warisan bisa tidak demikian, asalkan ada alasan tertentu yang diperbolehkan menurut hukum Islam, inilah yang disebut sulh (penerapan jalan damai).

Kata Kunci : Asas Keadilan, Pembagian Harta Warisan, Hukum Islam

\section{A. Pendahuluan}

Pelaksanaan hukum waris Islam di Indonesia sesuai dengan amanat Pancasila sila yang pertama yakni "Ketuhanan Yang Maha Esa", artinya penduduk negara Indonesia adalah manusia yang beragama dan percaya kepada Tuhan Allah yang satu (tauhid), ${ }^{1}$ realisasi dari kepercayaan tersebut berupa ketaatan pada perintah-Nya dan menjauhi larangan-Nya. Di samping itu juga sesuai dengan amanat UUD 1945 pasal 29 yang menjelaskan bahwa negara menjamin bagi tiap-tiap penduduk untuk percaya kepada Tuhan dan beribadah atau menjalankan ajarannya sesuai dengan ke- percayaannya. ${ }^{2} \mathrm{Hal}$ ini berarti negara memberikan perlindungan hukum bagi orang Islam untuk menjalankan ajaran agamanya termasuk menggunakan hukum waris Islam sebagai pedoman hukum dalam pembagian harta warisan.

Pelaksanaan hukum waris Islam di Indonesia mengalami kemajuan seiring dengan tumbuhnya kesadaran umat untuk mengamalkan hukum Islam. Oleh karena itu diperlukan landasan hukum supaya umat Islam mendapatkan kepastian dalammelaksanakan hukum waris Islam tersebut. Pemerintah melalui Instruksi Presiden No.1/ 1991menetapkan, bahwa Kompilasi Hukum Islam

1 Abdurrahman,1992, Kompilasi Hukum Islam di Indonesia, Jakarta, Akademika Pressindo, hlm.3.

2 Mardani, 2010, Hukum Islam, Pengantar Ilmu Hukum Islam di Indonesia, Yogyakarta, Pustaka Pelajar, hlm 163. 
(KHI) merupakan kumpulan pendapat para ahli hukum Islam (mujtahid) yang sudah disesuaikan dengan keadaan masyarakat Indonesia untuk digunakan sebagai landasan hukum bagi pelaksanaan hukum Islam termasuk waris Islam. ${ }^{3}$ Apabila ada permasalahan tentang hukum waris Islam, maka ahli waris yang tidak mendapatkan haknya dapat menggugat di Pengadilan Agama (PA), karena lembaga inilah yang dipercaya pemerintah dapat menyelesaikan permasalahan orang Islam termasuk hukum waris. PA dalam menyelesaikan kasus hukum tersebut berdasarkan UU No. 7/1989 jo UU No 3/2006 tentang Peradilan Agama.

Pada hukum waris Islam, mereka (para penganut gender) menggugat karena dalam hukum waris Islam terdapat penyimpangan gender yakni tidak adil dalam pembagian warisan karena kaum perempuan dapat bagian lebih sedikit dibanding lakilaki dengan rasio perbandingan $2: 1$, laki-laki dapat dua bagian dan perempuan satu bagian. Menurut konsep gender, ini adalah rasdiskriminasi perempuan dalam bentuk nyata.

Al-Qur'an surat An-Nisa' ayat11 mengajarkan bahwa "bagian seorang anak laki-laki sama dengan bagian dua anak perempuan". Kemudian KHI pasal 176 menjelaskan bahwa bagian antara laki-laki dan perempuan adalah dua berbanding satu. Bertitik tolak dari penjelasan tersebut dapat dipahami bahwa garis hukum bagian laki-laki dan perempuan adalah dua berbanding satu. Oleh karena itu permasalahan dalam tulisan ini akan membahas tentang mengapa garis hukum bagian lakilaki dan perempuan adalah dua berbanding satu dan bagaimanakah alasan hukumnya?. Tujuan penulisan ini untuk mendiskripsikan alasan hukum tentang bagian harta warisan antara laki-laki dan perempuan dalam hukum waris Islam serta untuk menganalisis pasal 176 KHI Inpres No.1/1991.

\section{B. Pembahasan}

\section{Diskursus Hukum Kewarisan Islam}

Dasar hukum kewarisan Islam selain terdapat dalam Al-Qur'an dan Al-Hadist juga terdapat dalam Ijtihad ulama. Di Indonesia hukum
Islamiyati, Analisis Asas Keadilan pada Pembagian Harta Warisan kewarisan Islam menjadi bagian dari hukum nasional karena aturannya telah disahkan oleh negara dalam bentuk perundang-undangan yakni Kompilasi Hukum Islam yang ditetapkan melalui Instruksi Presiden No. 1/1991 dan UU No 7/1989 jo UU No. 6/2003 tentang Peradilan Agama. Dengan demikian hukum waris Islam telah menjadi hukum positif yang harus dijadikan pedoman oleh orang Islam ketika menyelesaikan permasalahan hukum waris Islam. ${ }^{4}$

Hukum waris Islam berlaku ketika ada orang Islam meninggal dunia dan meninggalkan harta warisan dimana harta yang ditinggalkan oleh pewaris itu secara otomatis jatuh atau berpindah ke ahli waris, apabila tidak ada ahli waris maka harta warisan itu berpindah ke baitulmal atau diserahkan ke negara untuk digunakan oleh masyarakat. Dengan demikian hukum waris itu muncul jika ada pewaris (orang yang meninggal dunia), ahli waris (saudara yang ditinggalkan), tirkah (harta warisan) dan tidak ada penghalang ahli waris menerima harta warisan. Yang menghalangi ahli waris menerima harta warisan yakni ahli waris membunuh pewaris dan ahli waris tidak Islam atau murtad. ${ }^{5}$ Ketentuan ini ditambah oleh KHI pasal 173 yang menjelaskan bahwa penghalang ahli waris menerima harta warisan jika ahli waris membunuh atau mencoba membunuh atau melakukan perbuatan yang diancam hukuman penjara lebih dari lima tahun.

Kewajiban ahli waris terhadap pewaris sebagaimana terdapat dalam pasal $175 \mathrm{KHI}$ adalah:

a. Mengurus dan menyelesaikan sampai pemakaman jenazah selesai;

b. Menyelesaikan masalah utang-piutang,biaya pengobatan dan perawatan

c. Menyelesaikan wasiat pewaris;

d. Membagi harta warisan di antara ahli waris yang berhak.

e. Tanggung jawab terhadap hutang pewaris sebatas pada jumlah atau nilai harta peninggalan.

Harta warisan merupakan keseluruhan harta milik si pewaris, meliputi harta kekayaan yang berwujud dan tidak berwujud atau dalam bentuk

\footnotetext{
${ }^{3}$ Abdurrahman, Op. Cit, 14.

${ }^{4}$ Ahmad Rofiq, 2013, Hukum Islam di Indonesia, Jakarta, Rajawali Press, hlm 374.

${ }^{5}$ Zainuddin, 2007, Hukum Perdata Islam di Indonesia, Jakarta, Sinar Grafika, hlm.112-113.
} 
hutang, surat-surat berharga, harta bawaan dan harta gono-gini setelah dikurangi biaya perawatan jenazah, melunasi hutang dan pelaksanaan wasiat. ${ }^{6}$ Harta warisan inilah yang akan dibagioleh ahli waris. Adapun ahli waris adalah orang yang berhak mewaris karena hubungan kekerabatan atau hubungan darah/nasab, hubungan sebab perkawinan, beragama Islam dan tidak ada halangan untuk menerima warisan dari pewaris.

Menurut pasal 174 KHI menjelaskan bahwa kelompok ahli waris terdiri dari :

a. Menurut hubungan darah, yakni :

1) Golongan laki-laki terdiri dari; ayah, anak laki-laki, saudara laki-laki, kemenakan laki-laki, paman dan kakek.

2) Golongan perempuan terdiri dari; ibu, anak perempuan, saudara perempuan dan nenek.

b. Apabila semua ahli waris ada, maka yang berhak mendapat warisan hanya; anak, ayah, ibu, janda atau duda.

c. Menurut hubungan perkawinan, yakni: duda atau janda.

Dilihat dari segi haknya atas harta warisan, ahli waris dibagi menjadi tiga golongan, yaitu :

a. Dhawil furudl atau dzul faraid yaitu ahli waris yang berhak mendapatkan bagian tertentu seperti yang dijelaskan dalam AlQur'an dan Al-Hadist. Bagian tertentu itu adalah $2 / 3,1 / 2,1 / 4,1 / 8,1 / 3,1 / 6$.

1) $2 / 3$ untuk bagian $2 /$ lebih anak perempuan, 2/ lebih saudara kandung/ seayah.

2) $1 / 2$ untuk bagian seorang anak perempuan seorang saudara perempuan kandung/ seayah, suami bila pewaris tidak meninggalkan anak.

3) $1 / 4$ untuk bagian suami jika ada anak dan isteri jika pewaris tidak meninggalkan anak.
4) $1 / 6$ untuk bagian ayah dan ibu jika pewaris meninggalkan anak, ibu jikaada saudara lebih dari seorang, cucu perempuan dari anak laki-laki bersama seorang anak perempuan, saudara perempuan seayah bersama saudara perempuan kandung dan kakek jika pewaria meninggalkan anak.

5) $1 / 8$ untuk bagian isteri jika pewaris meninggalkan anak.

b. Ashabah yaitu ahli waris yang berhak menerima sisa dari pembagian harta warisan apabila terdapat kelebihan harta warisan, apabila tidak ada kelebihan harta warisan, mereka tidak menerima bagian warisan. Ashabah ada tiga macam:

1) Ashabah bil nafsi yakni ahli waris yang menerima sisa harta warisan secara sendirian, biasanya dari garis laki-laki, seperti; anak-laki, ayah, kakek.

2) Ashabah bil ghair yakni ahli waris yang sisa harta warisan karena ditarik oleh ahli waris lain. Seperti; anak perempuan ditarik menjadi ashabah anak laki-laki, cucu perempuan ditarik menjadi ashabah cucu laki-laki, saudara perempuan ditarik ashabah saudara laki-laki.

3) Ashabah ma'al ghair yakni ahli waris yang menjadi ashabah karena bersama dengan ahli waris lain, tetapi ahli waris tersebut tidak menjadi ashabah. Seperti saudara perempuan kandung atau seayah menjadi ashabah jika ada anak perempuan, tetapi anak perempuan tersebut tidak menjadi ashabah.

c. Dhawil arham yaitu ahli waris yang mempunyai hubungan persaudaraan dengan pewaris, tetapi tidak termasuk golongan ahli waris dhawil furudl dan ashabah. Seperti cucu-cucu perempuan atau laki-laki dari anak perempuan dan keturunan perempuan dari anak atau saudara perempuan. ${ }^{7}$ 


\section{Ahli Waris Laki-Laki dan Perempuan beserta Bagiannya}

Ahli waris merupakan orang yang berkewajiban menyelamatkan harta pewaris yang telah meninggal dari penyalahgunaan pihak-pihak yang tidak bertanggung jawab. Ahli warislah yang berhak menerima harta warisan dari pewaris yang telah meninggal setelah melaksanakan kewajibannya. Oleh karena itu dasar-dasar mewaris harus diperhatikan oleh para ahli waris, karena dasar mewaris merupakan dasar untuk menetapkan siapa saja yang mempunyai hubungan mewaris dengan pewaris yaitu ahli waris. Dasar penetapannya sesuai dengan garis hukum yang telah ditetapkan dalamAlQur'an,al-Hadist, perundang-undangan, Kompilasi Hukum Islam, pendapat para sahabat Rasullullah, dan pendapat para ahli hukum Islam melalui Ijtihadnya. ${ }^{8}$

Ahli waris dilihat dari segi jenis kelaminnya, dibagi menjadi dua, yakni :

a. Ahli waris laki-laki, berikut akan dijelaskan juga tentang kedudukan dan bagiannya, terdiri dari :

1) Suami, mendapatkan $1 / 2$ apabila isteri yang meninggal tidak mempunyai anak dan mendapatkan $1 / 4$ apabilasuaminya yang meninggal mempunyai anak. Suami termasuk ahli waris utama artinya selalu mendapat harta warisan dan tidak ada yang mengalanginya.

2) Anak laki-laki, mendapatkan semua harta warisan jika tidak ada ahli waris lain dan mendapatkan sisa (ashabah) bila ada pewaris yang lain, jika bersama dengan anak perempuan, maka bagiannya dua kali bagian dari anak perempuan. Anak laki-laki kedudukannya paling kuat dan menjadi penghalang / menghijab saudara lain untuk mendapatkan harta warisan.

3) Cucu laki-laki dari pancar laki-laki, mendapatkan bagian bila tidak ada anak lakilaki,bagian dan kedudukannya sama dengan anak laki-laki.

4) Ayah, mendapatkan 1/6 apabila bersama anak atau cucu laki-laki dari anak laki-laki, menjadi ashabah bila tidak ada anak atau cucu, dan mendapatkan 1/6 apabila bersama anak atau cucu perempuan.

5) Kakek, mendapatkan bagian apabila tidak ada ayah, apabila kakek menjadi ahli waris hanya bersama saudara laki-laki kandung, maka bagiannya adalah sama dengan saudara laki-laki atau 1/3, apabila bersama saudara perempuan kandung atau seayah dan ada ahli waris lain, maka kakek mendapatkan $1 / 6$ atau $1 / 3$.

6) Saudara laki-laki sekandung, tertutup / terhijab oleh anak laki-laki/ cucu laki-laki dari anak laki-laki, ayah/kakek, mendapatkan 1/ 6 apabila sendirian dan tidak ada ahli waris lain, mendapatkan $1 / 3$ apabila dua orang atau lebih dan tidak ada yang menghijabnya. Menjadi ashabah apabila bersama dengan saudara permpuan dengan ketentuan bagian saudara laki-laki dua kali bagian saudara permpuan.

7) Saudara laki-laki seayah, terhijab oleh saudara laki-laki dan perempuan kandung, menjadi ashabah bila tidak ada ahli waris lain, dan dapat menarik saudara perempuan seayah untuk menjadi ashabah dengan perbandingan dua banding satu.

8) Saudara laki-laki seibu, hanya mendapatkan bagian dari harta warisan ibu. Apabila sendirian dan tidak ada ahli waris lain, mendapatkan 1/6 apabila dua orang atau lebih dan tidak ada hali waris lain, mendapatkan $1 / 3$.

9) Anak laki-laki dari saudara laki-laki sekandung dan anak laki-laki keturunannya tanpa diselingi oleh anak perempuan, terhijab oleh saudara laki-laki kandung dan saudara laki-laki seayah, kakek dan seterusnya ke atas dari garis laki-laki.

10) Anak laki-laki dari saudara laki-laki seayah dan anak laki-laki keturunannya tanpa diselingi oleh anak perempuan, ketentuannya sama dengan kemenakan laki-laki kandung, tetapi tertutup juga oleh kemenakan laki-

${ }^{8}$ Ahmad Rofiq, Op. Cit., hlm. 374. 
laki kandung tersebut.

11) Paman sekandung, merupakan ahli waris jauh karena tertutup oleh kemenakan lakilaki kandung, seayah serta anak keturunannya yang laki-laki.

12) Paman seayah, ketentuannya sama dengan paman kandung, tetapi tertutup juga oleh paman kandung tersebut.

13) Anak laki-laki dari paman sekandung dan anak laki-lakiketurunannya tanpa diselingi oleh anak perempuan, terhijab oleh paman seayah dan juga oleh paman seayah sendiri.

14) Anak laki-laki dari paman seayah dan anak laki-laki keturunannya tanpa diselingi oleh anak perempuan, ketentuannya sama dengan kemenakan laki-laki kandung, tetapi tertutup juga oleh kemenakan laki-laki kandung tersebut.

b. Ahli waris perempuan, berikut akan dijelaskan juga tentang kedudukan dan bagiannya, terdiri dari:

1) Isteri, mendapatkan $1 / 4$ apabila suaminya yang meninggal tidak mempunyai anak, dan mendapatkan $1 / 8$ apabila suaminya yang meninggal mempunyai anak. Isteri termasuk ahli waris utama artinya isteri tersebut selalu mendapat harta warisan dan tidak ada yang mengalanginya.

2) Anak perempuan,mendapatkan $1 / 2$ apabila sendirian tidak ada anak laki-laki, 2/3 apabila jumlahnya dua/lebih dan tidak ada anak laki-laki, menjadi ashabah apabila bersama anak laki-laki dengan bagian seorang anak laki-laki sama dengan dua anak perempuan.

3) Cucu perempuan dari pancar laki-laki, berkedudukan seperti anak perempuan, apabila ada dua anak perempuan, maka cucu perempuan tidak dapat, kecuali ditarik cucu laki-laki dari anak laki-laki. Cucu perempuan dapat $1 / 2$ apabila sendirian, tidak ada anak dan tidak ada cucu laki-laki. Mendapatkan $2 / 3$ apabila dua orang atau lebih, tidak ada anak dan tidak ada cucu laki-laki.
Mendapatkan 1/6 apabila bersama seorang anak perempuan, menjadi ashabah apabila ada cucu laki-laki dengan bagian seorang cucu laki-laki sama dengan dua cucu perempuan. Tidak mendapatkan harta warisan apabila ada anak laki-laki dan dua atau lebih anak perempuan.

4) Ibu,mendapatkan $1 / 6$ apabila ada anak atau cucu atau lebih dari seorang saudara, mendapatkan $1 / 3$ apabila tidak ada anak, cucu atau lebih dari seorang saudara. Isteri termasuk ahli waris utama artinya isteri tersebut selalu mendapat harta warisan dan tidak ada yang mengalanginya.

5) Nenek, Nenek, mendapatkan $1 / 6$ apabila tidak ada ibu, apabila ada ibu maka nenek tidak mendapatkan harta warisan.

6) Saudara perempuan kandung, mendapatkan $1 / 2$ apabila sendirian, tidak ada anak, cucu pancar anak laki-laki, ayah, dan tidak ada yang menariknya menjadi ashabah (saudara laki-laki kandung). Mendapatkan 2/3 apabila jumlahnya dua atau lebih, tidak ada anak, cucu pancar anak laki-laki, ayah, dan tidak ada yang menariknya menjadi ashabah (saudara laki-laki kandung).

Menjadi ashabah apabila ada saudara lakilaki. Tidak mendapatkan harta warisan apabila ada ayah, anak laki-laki atau cucu pancar anak laki-laki.

7) Saudara perempuan seayah, mendapatkan $1 / 2$ apabila sendirian, tidak ada anak, ayah, cucu pancar anak laki-laki, saudara kandung, dan tidak ada yang menariknya menjadi ashabah (anak perempuan atau cucu perempuan dari anak laki-laki). Mendapatkan $2 / 3$ apabila jumlahnya dua atau lebih, tidak ada anak, cucu pancar anak laki-laki, ayah, saudara kandung, dan tidak ada yang menariknya menjadi ashabah (anak perempuan atau cucu perempuan dari anak lakilaki). Menjadi ashabah apabila bersama dengan anak perempuan atau cucu perem- 
puan dari anak laki-laki. Tidak mendapatkan harta warisan apabila ada ayah, anak lakilaki atau cucu pancar anak laki-laki, saudara perempuan kandung. ${ }^{9}$

8) Saudara perempuan seibu, mendapatkan $1 / 2$ apabila sendirian, tidak ada anak, ayah, cucu pancar anak laki-laki, saudara kandung, dan tidak ada yang menariknya menjadi ashabah (anak perempuan atau cucu perempuan dari anak laki-laki). Mendapatkan 2/3 apabila jumlahnya dua atau lebih, tidak ada anak, cucu pancar anak laki-laki, ayah, saudara kandung, dan tidak ada yang menariknya menjadi ashabah (anak perempuan atau cucu perempuan dari anak lakilaki). Menjadi ashabah apabila bersama dengan anak perempuan atau cucu perempuan dari anak laki-laki. Tidak mendapatkan harta warisan apabila ada ayah, anak lakilaki atau cucu pancar anak laki-laki, saudara perempuan kandung. ${ }^{10}$

Ahli waris perempuan yang menerima harta warisan adalah yang mempunyai hubungan dekat/ langsung dengan pewaris dan tidak terhijab/tertutup dari ahli waris lain termasuk laki-laki. Misalnya cucu perempuan dari anak laki-laki berkedudukan sebagai pengganti anak laki-laki.

\section{Analisis terhadap Asas Keadilan dalam Hukum Waris Islam}

Bertitik tolak dari penjelasan di atas, memahamkan bahwa ahli waris menurut huku waris Islam berasal dari garis keturunan laki-laki dan perempuan, serta dari hubungan perkawinan. Hal ini berbeda dengan jaman sebelum ajaran Islam datang, di mana pembagian harta warisan didasarkan pada nasab atau kekerabatan laki-laki, karena laki-lakilah yang mampu berperang mengusir musuh dan merampas harta peperangan demi menjaga kehormatan keluarga. ${ }^{11}$ Sedangkan perempuan tidak mendapatkan harta warisan karena
Islamiyati, Analisis Asas Keadilan pada Pembagian Harta Warisan tidaktermasuk ahli waris bahkan menjadi harta warisan yang berhak diwariskan kepada kerabat laki-laki, terlepas apakah wanita tersebut rela atau tidak. $^{12}$

Apabila diurai tentang bobot tanggung jawab peranan antara laki-laki dan perempuan, dapat dikatakan bahwa tanggung jawab laki-laki lebih besar daripada perempuan. Hal ini sesuai dengan pasal $176 \mathrm{KHI}$ yang berbunyi:

"Anak perempuan bila hanya seorang ia mendapat separoh bagian, bila dua orang atau lebihmereka bersama-sama mendapat dua pertiga bagian, dan apabila anak perempuan bersamasamadengan anak laki-laki, maka bagian anak lakilaki adalah dua berbanding satu dengan anakperempuan". ${ }^{13}$

Pasal di atas mengandung garis hukum, yaitu :

a. Anak perempuan dan anak laki-laki adalah ahli waris dariorang tuanya. Ini menunjukkan bahwa sistem kewarisan Islam adalah bilateral, artinya sistem kewarisan yang ahli warisnya berasal dari keturunan laki-laki dan perempuan.

b. Apabila ahli waris terdiri dari seorang anak perempuan, tidak ada anak laki-laki, maka anak perempuan tersebut berhak mendapatkan warisan $1 / 2$.

c. Apabila ahli waris terdiri dari dua atau tiga anak perempuan, tidak ada anak laki-laki, maka beberapa anak perempuan tersebut berhak mendapatkan warisan 2/3.

d. Apabila ahli waris terdiri dari anak perempuan dan anak laki-laki, maka keduanya adalah ashabah bil ghair dengan porsi pembagian satu untuk anak perempuan dan dua untuk anak laki-laki.

Kedudukan ahli waris laki-laki adalah ashabah bi-nafsi, baik sendirian atau lebih dari seorang. Apabila bersama anak perempuan, maka bisa menarik anak perempuan tersebut menjadi ashabah. Kedudukan anak laki-laki sangat kuat dalam hukum kewarisan Islam, keberadaannya

\footnotetext{
${ }^{9}$ Ahmad Azhar Basyir, Op. Cit., hlm. 43-62.

${ }^{10}$ Ahmad Azhar Basyir, Op. Cit., hlm. 43-62.

${ }^{11}$ Asymuni A. Rahman dkk, 1986, Ilmu Fiqh Jilid III, Jakarta, Dirjen DEPAG RI, h. 6.

${ }^{12}$ Asymuni A. Rahman dkk, Op. Cit., hlm. 7.

${ }^{13}$ Ibid., hlm 157
} 
dapat menutup ahli waris bukan utama untuk menerima harta warisan. Laki-laki mendapatkan bagian harta warisan lebih banyak daripada perempuan, bukan berarti itu tidak adil,karena adil merupakan penempatan sesuatu pada tempatnya, termasuk memberikan bagian warisan pada laki-laki banyak karena kewajibannya juga banyak, antara lain:

a. Mencukupi nafkah berupa sandang, pangan, papan bagi isteri dan anaknya, termasuk kebutuhan rumah tangga.

b. Memelihara kerabat lain atau mencukupi kebutuhannya, apabila telah lemah,misalnya; orang tua, saudara perempuan.

c. Memberikan mahar ketika akan menikahi seorang perempuan.

d. Memberikan mut'ah dan nafkah iddah ketika menceraikan isterinya.

e. Memberikan biaya perawatan, kesehatan dan pendidikan anaknya. ${ }^{14}$

Sedangkan kewajiban wanita dalam rumah tangga hanya sebatas kewajiban non materi/ tidak kebendaan, bahkan yang diperoleh wanita terhadap hak kebendaan sangat banyak antara lain :

a. Apabila isteri telah menikah, maka ia mendapatkan nafkah dari suami. Segala keperluan hidupnya yang menanggung suami, baik pangan, papan, sandang, maupun kebutuhan dan peralatan rumah tangga. ${ }^{15}$

b. Apabila belum menikah, maka yang mencukupi segala kebutuhannya ialah orang tuanya sampai ia dewasa/mandiri atau menikah.

c. Apabila telah dewasa/mandiri tetapi belum menikah dan kaya, maka segala kepemilikannya adalah hak penuh miliknya.

d. Apabila telah dewasa/mandiri tetapi belum menikah dan tidak mampu, maka segala beaya kebutuhan hidupnya yang menanggung orang tua dan saudara lakilakinya atau kerabatnya. e. Apabila telah tua dan mempunyai anak dan tidak mampu, maka yang mencukupi segala kebutuhannya adalah anak-anaknya. ${ }^{16}$

Dari penjelasan di atas, dapat dipahami bahwa kepemilikan harta bagi wanita bersifat individul artinya harta benda tersebut milik penuh wanita dan menurut hukum tidak ada kewajiban untuk diberikan kepada yang lain. Begitu juga ketika wanita itu menerima harta warisan, maka harta warisan tersebut adalah miliknya penuh. Dari pernyataan ini dapat dikatakan bahwa apabila para wanita menerima separo bagian dari satu bagian milik laki-laki, hal itu sesuai dengan asas hukum kewarisan Islam yaitu keadilan berimbang, penerimaan harta warisan sesuai dengan hak dan kewajibannya. ${ }^{17}$

Konsep keadilan apabila dianalisis, maka dalam hukum waris Islammenganut konsep keadilan distributif (justicia distributiva) artinya suatu keadilan yang memberikan kepada setiap orang didasarkan atas jasa-jasanya, atau pembagian menurut haknya masing-masing. ${ }^{18}$ Hak diberikan sesuai dengan kewajiban yang dilakukan. Begitu juga dalam pemberian bagian warisan antara anak lakilaki dan anak perempuan. Anak laki-laki mendapatkan hak menerima bagian warisan lebih banyak, karena kewajiban yang diembannya juga banyak.

Hazairin berpendapat bahwa konsep keadilan menurut hukum waris Islam, terdiri dari empat unsur, yakni ${ }^{19}$ :

1) Keadilam Metafisis, artinya keadilan yang mengandung dua nilai keadilan yaitu nilai keadilan Tuhan dan manusia. Hukum akan berlaku adil apabila terdapat keterpaduan antara nilai-nilai yang terdapat dalam pesan hukum dariAl-Qur'an, al-Hadist dan Ijtihad dengan masyarakat sebagai orang yang secara langsung dibebani untuk menjalankan hukum.

\footnotetext{
${ }^{14}$ Muhammad Ali al-Shabuni, 1305 H/1985M,Al-Mawarist fi al-Syari'ah al-Islamiyah fi da'u al-Kitab wa al-Sunnah, Makkah, Alam al- Kutub, hlm 17.

${ }^{15}$ Ahmad Azhar Basyir, Ibid, hlm 161.

${ }^{16}$ Amir Syarifuddin, 2006, Hukum Perkawinan Islam di Indonesia (Antara Fiqh Munakahat dan UU Perkawinan), Kencana, Jakarta,.hlm 333. Lihat KHI pasal 46,

${ }^{17}$ Ahmad Azhar Basyir, Op. Cit., hlm 11

${ }^{18}$ R. Soeroso, 1993, Pengantar Ilmu Hukum, Jakarta, Sinar Grafika, hlm. 63-64.

${ }^{19}$ Abdul Ghofur Anshori, Filsafat Hukum Kewarisan Islam (Konsep Kewarisan Bilateral Hazairin), Yogyakarta, UII Press, 2005, hal. 158-176.
} 
2) KeadilanAntropologis, adalah keadilan yang didasarkan pada pendapat manusia yang beragam berdasarkan budaya yang tumbuh di masyarakat. Hukum waris Islam merupakan hukum teoritis berdasarkan AlQur'an, al-Hadist dan Ijtihad. Hukum ini digunakan sebagai acuan kerangka norma dasar bagi orang Islam di masyarakat. Hukum ini mempunyai nilai keadilan apabila ada upaya membangkitkan penilaian keadilan berdasarkan keyakinan di masyarakat, sehingga muncul kesadaran untuk membiasakan berhukum berdasarkan keyakinan tersebut.

3) Keadilan Gender, adalah keadilan yang tidak didasarkan pada jenis kelamin, artinya antara laki-laki dan perempuan mempunyai kesempatan sama untuk memperoleh keadilan. Pada hukum waris Islam menjelaskan bahwa laki-laki dan perempuan berkedudukan sama sebagai ahli waris, baik sebagai ahli waris utama, maupun pengganti (mawalli), tentang perbedaan pembagian harta warisan tentunya ada alasan yang melatar belakanginya.

4) Keadilan Hukum, adalah keadilan yang berhubungan dengan hak, kewajiban, dan pelanggaran yang berasal dari pengaruh individu dan sosial. Keadilan hukum menurut Hazairin ada dua, yakni keadilan yang diputuskan oleh manusia (insani) sebagai hasil interaksinya dengan kehidupan sosial dan keadilan yang diputuskan oleh Tuhan Allah (illahi) sebagai keterikatan ketundukan dan kepatuhan. Oleh karena itu orang Islam tentunya mempunyai pedoman dasar dalam pengambilan keputusan berdasarkan keadilan Tuhan yang diterima sebagai keadilan manusia dalam kehidupan.

Berdasarkan penjelasan di atas, dapat dipahami bahwa ketentuan dalam hukum kewarisan Islam adalah aturan dari hukum Allah yang harus ditaati. Apabila ahli waris sudah menerima bagian
Islamiyati, Analisis Asas Keadilan pada Pembagian Harta Warisan masing-masing, maka dia berhak mengelolanya. Jika ingin memberikan bagiannya kepada ahli waris lain, misalnya ahli waris perempuan, sehingga bagian perempuan sama dengan bagian laki-laki. Menurut hukum waris Islam boleh-boleh saja, dan inilah yang disebut damai (tashaluh).

Tashaluh artinya pembagian harta warisan yang didasarkan pada prinsip perdamaian dengan cara ahli waris tertentu merelakan bagiannya untuk diberikan kepada ahli waris lain, setelah ia mengetahui bagiannya. Tujuan perdamaian ini adalah untuk menyelesaikan pertengkaran atau perselisihan di antara ahli waris. ${ }^{20}$ Perdamaian dibolehkan dalam hukum Islam tanpa melalui jalur hukum, tetapi harus didasari musyawarah untuk mengambil kesepakatan. Hal ini seseai dengan Al-Qur'an surat an-Nisa' ayat 128, artinya:

"Dan jika seorang wanita khawatir akan nusyus atau sikap tidak acuh dari suaminya, maka tidak mengapa bagi keduanya mengadakan perdamaian yang sebenar-benarnya, dan perdamaian itu lebih baik (bagi mereka) walaupun manusia itu menurut tabiatnya kikir". ${ }^{21}$

Ayat tersebut menjelaskan tentang konsep perdamaian yang digunakan untuk menyelesaikan perselisihan dan menghilangkan rasa dendam. Perdamaian boleh dilakukan dalam hukum kewarisan Islam apabila telah memenuhi syarat, yaitu:

a. Para ahli waris telah mengetahui bagiannya terlebih dahulu berdasarkan ketentuan hukum waris Islam.

b. Tanpa paksaan atau dilaksanakan dengan penuh kesadaran, artinya ahli waris tidak dipaksa atau merelakan bagiannya dikurangi untuk diberikan bagiannya kepada ahli waris lain, dengan penuh kesadaran demi menciptakan kebaikan bagi para ahli waris. ${ }^{22}$

c. Tidak bertujuan untuk menghalalkan yang haram dan mengharamkan yang halal. Artinya pelaksanaan pembagian warisan harus berdasarkan hukum Allah, tidak mengada-ada sehingga terhindar dari larangan-larang yang diharamkan. ${ }^{23}$

${ }^{20}$ Muhammad Amin al-Syahir bin 'Abidin, 1994, Radd al-Mukhtar, Dar al- Kutub, Beirut-Libanon, hlm. 405.

${ }^{21}$ Departemen Agama RI, Op. Cit., hlm. 143.

${ }^{22}$ Thoha Abdurrahman, 1975, Pembahasan Waris dan Menurut Hukum Islam, Sumbangsih, Yogyakarta, hlm. 101.

${ }^{23}$ Imam Muhammad bin Ismail al-Amir al-Yamani al-Sinai, 1988, Subul al-Salam SyarhBulugh al-Maram min Jami'Adil Al-Ahkam, Dar al-Kutub al-'Ilmiyah, Beirut-Libanon, hlm 111. 
d. Tidak mengandung unsur penipuan.

e. Mengandung kemashlahatan dan menolak kemadharatan, dilaksanakan demi kebaikan untuk menjaga kerukunan.

Keberadaan tashaluh (perdamaian) menjadikan hukum kewarisan Islam tidak terkesan kaku dan tekstual, tetapi bisa berubah dalam kasus tertentu apabila mengandung kemashlahatan dan menghindarkan kerugian. Hal ini sesuai dengan ketentuan pasal $183 \mathrm{KHI}$ yang berbunyi 'Para ahli waris dapat bersepakat melakukan perdamaian dalam pembagian harta warisan, setelah masingmasing menyadari bagiannya". ${ }^{24}$ Apabila dicermati ternyata perdamaian dapat menghilangkan perselisihan atau sengketa dalam hubungan persaudaraan, dan inilah yang dikehendaki oleh tujuan hukum kewarisan Islam. ${ }^{25}$

\section{Simpulan}

Berdasarkan paparan tulisan di atas dapat disimpulkan bahwa salah satu asas hukum kewarisan Islam adalah bilateral, artinya yang berhak menjadi ahli waris adalah keturunan laki-laki dan perempuan. Hal ini sesuai dengan prinsip hukum Islam yang menganut asas persamaan dan pemuliaan harkat dan martabat manusia dan sesuai juga dengan Q.S. AnNisa' ayat 7 dan pasal 174 KHI.Berdasarkan pasal 176 KHI dan Q. S. An-Nisa' ayat 11 menjelaskan bahwa porsi bagian antara anak laki-laki dan anak perempuan berbanding 2: 1, karena kewajiban lakilaki lebih banyak daripada perempuan. Hukum kewarisan Islam berprinsip keadilan berimbang, artinya pembagian warisan disesuaikan besar kecilnya hak yang diperoleh dan kewajiban yang harus dilaksankan. Dengan demikian keadilan yang digunakan adalah keadilan distributif (justicia distributiva) artinya suatu keadilan yang memberikan kepada setiap orang didasarkan atas jasa-jasanya, atau pembagian menurut haknya masing-masing.

\section{DAFTAR PUSTAKA}

Azhar Basyir, Ahmad, 2009, Hukum Waris Islam, Ed. Revisi, Yogyakarta: UII Press.

Abdurrahman, 1992, Kompilasi Hukum Islam di Indonesia, Jakarta: Akademika Pressindo.

Abdurrahman, Thoha, 1975, Pembahasan Waris dan Menurut Hukum Islam, Sumbangsih, Yogyakarta.

Amin al-Syahir bin 'Abidin, Muhammad, 1994, Radd al-Mukhtar, Dar al- Kutub: BeirutLibanon.

Ali, Zainuddin, 2007 Hukum Perdata Islam di Indonesia, Jakarta: Sinar Grafika.

A. Rahman, Asymuni dkk,1986, Ilmu Fiqh Jilid III, Jakarta: Dirjen DEPAG RI.

Ali al-Shabuni, Muhammad, 1305 H/ 1985, AlMawarist fi Al-Syari'ah al-Islamiyah fi da'u al-Kitab wa al-Sunnah, Makkah: Alam al- Kutub.

Depag RI, 1989, Al-Qur'an dan Terjemahnya, Semarang: CV Toha Putra.

Ghofur Anshori, Abdul, 2005,Filsafat Hukum Kewarisan Islam (Konsep Kewarisan Bilateral Hazairin), Yogyakarta, UII Press.

Hasan, Sofyan dan Warkum Sumitro, 1994, DasarDasar Memahami Hukum Islam di Indonesia, Surabaya: Karya Anda.

Mardani, 2010, Hukum Islam, Pengantar Ilmu Hukum Islam di Indonesia, Yogyakarta: Pustaka Pelajar.

\footnotetext{
${ }^{24}$ Abdurrahman, Op. Cit., hlm 158.

${ }^{25}$ Rokhmadi, 2002, Sulh dalam Pembagian Warisan (Studi Hukum Islam Terhadap Pasal 183 KHI), Jurnal Al-Ahkam, Vol XIII, Edisi I, Juli 2002, Fakultas Syari' ah IAIN Walisongo, Semarang, hlm 123
} 
Muhammad bin Ismail al-Amir al-Yamani al-Sinai, Imam, 1988, Subul al-Salam SyarhBulugh al-Maram min Jami' Adil Al-Ahkam, Dar alKutub al-'Ilmiyah: Beirut-Libanon.

R. Soeroso, 1993, Pengantar Ilmu Hukum, Jakarta: Sinar Grafika.

Rofiq, Ahmad, 1997, Hukum Islam di Indonesia, Jakarta: Rajawali Press.

Rokhmadi, Sulh dalam Pembagian Warisan (Studi Hukum Islam Terhadap Pasal 183 KHI), 2002, Jurnal Al-Ahkam, Vol XIII, Edisi I, Juli 2002, Fakultas Syari'ah IAIN Walisongo: Semarang.

Syarifuddin, Amir, 2008, Hukum Kewarisan Islam, Jakarta: Kencana.

Syarifuddin, Amir,2006, Hukum Perkawinan Islam di Indonesia (Antara Fiqh Munakahat dan UU Perkawinan), Jakarta:

Kencana. 